\title{
Exposure to sunlight and vitamin D deficiency in Saudi Arabian women
}

\author{
V. FONSECA* \\ M.D., M.R.C.P.
M. EL-HAZMI
Ph.D.

R. TONGIA

M.D., M.R.C.P.

H. ABU-AISHA

M.D., M.R.C.P.

College of Medicine, King Saud University, Riyadh, Saudi Arabia

\section{Summary}

Plasma 25-hydroxy cholecalciferol (25-OH vitamin D) concentrations were measured in 31 adult Saudi Arabian women who presented with acute minor illness. Patients with chronic diseases, malignancy and overt metabolic bone disease were excluded from this study. The median plasma 25-OH vitamin D concentration was $6 \mathrm{ng} / \mathrm{ml}$ (range: $2-18 \mathrm{ng} / \mathrm{ml}$ ). Only three subjects had a concentration within the normal range (10-55 $\mathrm{ng} / \mathrm{ml})$. Plasma 25-OH vitamin D concentrations were significantly lower in subjects living in apartments than in those living in villas or rural areas $(P<0.02)$. When direct questioning was used to assess exposure to sunlight, plasma 25-OH vitamin $D$ concentrations were significantly lower in those subjects whose average exposure was less than $30 \mathrm{~min}$ daily than those whose exposure was more than 30 min daily $(P=0.002)$.

Our findings confirm the importance of inadequate exposure to sunlight in the aetiology of vitamin D deficiency. Social customs may contribute to this deficiency in spite of abundant sunshine.

Direct questioning to assess the adequacy of sunlight exposure is an essential part of history taking in cases of suspected vitamin D deficiency.

KEY WORDS: plasma 25-hydroxy cholecalciferol, plasma alkaline phosphatase.

\section{Introduction}

In the last 2 decades, vitamin $\mathrm{D}$ deficiency rickets and osteomalacia have emerged as major problems in Asians in Britain (Preece et al., 1973). This has been attributed to dietary factors like vegetarianism and also in part to inadequate exposure to sunlight. Skin pigmentation in Asian subjects also reduces the

\footnotetext{
* Present address: Metabolic Unit, Department of Chemical Pathology, Royal Free Hospital and School of Medicine, Pond Street, London NW3 2QG.
}

penetration of ultra-violet (u.v.) light into the skin and hence diminishes the cutaneous production of vitamin $\mathrm{D}_{3}$ (Clemens et al., 1982). We were therefore surprised that rickets and osteomalacia, particularly in infants and lactating women, are common in Saudi Arabia, a land with abundant sunshine, where there are few, if any, vegetarians (Serenius, Elidrissy and Dandona, 1984).

Since most Saudi women cover themselves in dark veils, we wondered whether this practice might be responsible for inadequate exposure to sunlight resulting in vitamin $\mathrm{D}$ deficiency. Furthermore, the recent prosperity in Saudi Arabia has led to a sudden urbanization and the housing of an increasing section of the population in air-conditioned apartments in which direct entry of sunlight is obstructed by walls or glass. We therefore embarked on an investigation to establish whether inadequate exposure to sunlight might well be the mechanism underlying hypovitaminosis D in Saudi women.

\section{Patients and methods}

Thirty-one adult Saudi Arabian females who attended the primary care unit of the hospital for acute minor illnesses were included in the study. The median age was 45 years (range 22-65). A history was obtained and physical examination performed in all subjects. The following were excluded from the study: (a) subjects who had been pregnant and/or lactated within the previous 2 years; (b) those suffering from chronic diseases causing restriction in mobility for more than 1 month; (c) those with metabolic bone disease; (d) those taking anticonvulsants; and (3) those with malignant disease.

All subjects stated that they covered all parts of their body, including the face, when in public in accordance with social customs. Subjects were asked about the type of residence they lived in and whether 
they exposed themselves to sunlight without a veil for an average of at least $30 \mathrm{~min}$ daily.

Some of the subjects were interviewed by a dietician and their dietary vitamin $\mathrm{D}$ intake was estimated to be similar to the average estimated by our hospital dietetic department (40 iu/day in rural Saudis and $70 \mathrm{iu} /$ day in urban Saudis).

Serum calcium was measured using a Corning Calcium Analyser 940; plasma phosphate and alkaline phosphatase were measured by Technicon autoanalyser. Plasma was stored at $-20^{\circ} \mathrm{C}$ and transported in the frozen state to West Germany. Plasma 25hydroxy vitamin $D$ was measured commercially by Bioscienta Laboratories, Mainz, West Germany, using competitive protein binding. The normal range in this laboratory for Caucasians is $10-55 \mathrm{ng} / \mathrm{ml}$ (25-138 nmol/litre).

Statistical analysis was carried out using the Mann-Whitney $U$-test.

\section{Results}

The median plasma $25-\mathrm{OH}$ vitamin $\mathrm{D}$ in our subjects was $6 \mathrm{ng} / \mathrm{ml}$ (range $2-18 \mathrm{ng} / \mathrm{ml}$ ). Only 3 women had a concentration above the lower limit of the normal range of the laboratory (in West Germany). In 3 subjects plasma $25-\mathrm{OH}$ vitamin D was undetectable $(<2 \mathrm{ng} / \mathrm{ml})$. Serum calcium and phosphate concentrations were within the normal range in all subjects. Plasma alkaline phosphatase activity was raised in 5 subjects (median: 105; range 50-155 iu/litre, normal range for the laboratory: 35-130 $\mathrm{iu} /$ litre); the concentration of $25-\mathrm{OH}$ vitamin $\mathrm{D}$ in these subjects was not lower than that in the rest: median $6 \mathrm{ng} / \mathrm{ml}$ (range $2-15 \mathrm{ng} / \mathrm{ml}$ ). The plasma concentrations of calcium, phosphate and alkaline phosphatase activity were not related to those of 25OH vitamin D.

Table 1 summarizes our findings when the subjects were divided into groups according to the type of residence they lived in and according to whether their average daily exposure to sunlight was less or more than $30 \mathrm{~min}$. It shows that women who live in apartments and those who admitted to under $30 \mathrm{~min} \frac{3}{8}$

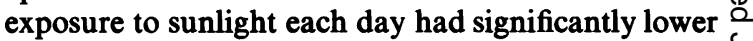
plasma $25-\mathrm{OH}$ vitamin D levels than those living in villas and having more sunlight exposure.

\section{Discussion}

In 1889 , a survey of the incidence of rickets in the British Isles showed that rickets abounded in densely populated urbanized areas, but was essentially absent of in the rural districts (Owen, 1889).

Since then, it has been well recognized that inadequate exposure to sunlight plays an important $\vec{\omega}$ role in the aetiology of rickets and osteomalacia. This fact is emphasized by the data in our study. Due to 0 social customs, women in Saudi Arabia are not exposed to adequate sunlight. Rural dwellers and those living in villas with courtyards are able to get more exposure to sunlight than those living in airconditioned apartments in which direct entry of $O$ sunlight is obstructed by walls or glass. The subjects' own estimate of the adequacy of their sunlight exposure has proved to be reliable in our study. $\vec{i}$ Quantitating sunlight exposure by questionnaire has $\mathbb{D}$ been found to be useful in a study of osteomalacia in the elderly (Hodkinson et al., 1973). Direct questioning of patients to assess adequacy of their exposure to $\mathbb{D}$ sunlight is thus an essential part of history taking i⿱⺈ cases of suspected vitamin D deficiency.

The estimated dietary vitamin D intake in Sauds is low in comparison to the recommended Western daily dietary allowance of $\mathbf{4 0 0}$ iu (Food and Nutrition Board, 1968). Dietary inadequacy of vitamin D may play a role in the aetiology of vitamin $D$ deficiency in our subjects, but this could easily be $\stackrel{\mathbb{Q}}{\varrho}$ overcome by adequate exposure to sunlight (Gupta, $\overrightarrow{\vec{O}}$ Round and Stamp, 1974). Rural dwellers with a 3 lower dietary intake than urban dwellers had higher $\supset$ plasma 25-OH vitamin D in our study. Skin pigmentation, which is known to reduce the capacity of skin to synthesize vitamin $D_{3}$ (Clemens et al., 1982), may contribute by decreasing the usefulness of the little sunlight to which our subjects are exposed.

TABLE 1. Plasma 25-OH vitamin D levels in Saudi Arabian women

\begin{tabular}{lcccc}
\hline & $\begin{array}{c}\text { Total } \\
\text { number }\end{array}$ & Median & Range & Significance* \\
\cline { 3 - 5 } Villa/rural dwellers & 21 & 7.5 & $<2-18$ & \\
Apartment dwellers & 10 & 4 & $<2-15$ & $P<0.02$ \\
$\begin{array}{l}\text { Daily sunlight exposure } \\
>30 \text { min }\end{array}$ & 15 & 8 & $<2-18$ & \\
$<30$ min & 16 & 5 & $<2-8$ & $P=0.002$ \\
\hline
\end{tabular}

*Mann-Whitney $U$-test. 
In spite of the low plasma 25-OH vitamin D levels, none of our subjects had overt osteomalacia. Similar findings have been reported in Asian immigrants in Britain (Preece et al., 1973). A normal concentration of serum calcium in Asians with vitamin D deficiency can be accounted for by increased secretion of parathyroid hormone (Stanbury, 1981; Dandona et al., 1984). Stanbury has termed this early stage of vitamin $D$ deficiency as a state of 'normocalcaemic secondary hyperparathyroidism'. With developing vitamin D depletion, secondary hyperparathyroidism could sustain the level of serum 1,25 dihydroxyvitamin $D\left(1,25-[\mathrm{OH}]_{2}\right.$ vitamin $\left.\mathrm{D}\right)$ in the face of a diminishing serum $25-\mathrm{OH}$ vitamin $\mathrm{D}$. Thus a vitamin D-depleted population may be expected to include individuals in whom this adaptive process is effective, resulting in normal or possibly even increased levels of serum 1,25-(OH) $)_{2}$ vitamin $D$ and no clinical osteomalacia. When this process fails, the serum $1,25-(\mathrm{OH})_{2}$ vitamin $\mathrm{D}$ concentrations become subnormal and clinical osteomalacia develops.

In conclusion, the aetiology of vitamin $\mathrm{D}$ deficiency in Saudi Arabian women is multifactorial, with inadequacy of diet and sunlight exposure as well as skin pigmentation playing a role. Inadequate exposure to sunlight due to social customs and urbanization is the most important factor, with the deficiency being partly overcome in some subjects who expose themselves to sunlight.

\section{Acknowledgments}

We thank Drs P. Dandona and D. P. Mikhailidis, Department of Chemical Pathology, Royal Free Hospital School of Medicine, London, U.K., for their help and advice, and B. Bettigrew and P. Dale for their assistance in the preparation of the manuscript.

\section{References}

Clemens, T.L., Adams, J.S., Henderson, S.L. \& Holick, M.F. (1982) Increased skin pigment reduces the capacity of skin to synthesise vitamin $\mathrm{D}_{3}$. Lancet, $\mathrm{i}, 74$.

Dandona, P., Mohiuddin, J., Weerakoon, J.W., Freedman, D.B., FonSECA, V. \& HeALY, T. (1984) Is a normal plasma calcium in an Asian vegetarian really normal? Evidence for frequent autonomous parathyroid hormone secretion. Journal of Clinical Endocrinology and Metabolism, (in press).

FOOD AND NUTRITION BOARD, (1968) Recommended Dietary Allowances, 7th edn, National Research Council publication No. 1694, National Academy of Sciences, Washington.

GuPTA, M.M., RouND, J.M. \& STAMP, T.C.B. (1974) Spontaneous cure of vitamin D deficiency in Asians during summer in Britain. Lancet, i, 586.

Hodkinson, C.M., Stanton, B.R., Round, P. \& Morgan, C. (1973) Sunlight, vitamin D and osteomalacia in the elderly. Lancet, i, 910.

OWEN, I. (1889) Geographical distribution of rickets, acute and subacute rheumatism, chorea, cancer and urinary calculus in the British Islands. British Medical Journal, 1, 113.

Preece, M.A., Ford, J.A., McInTosh, W.B., DunNigan, M.G., TOMLINSON, S. \& O'RIORDAN, J.L.M. (1973) Vitamin D deficiency among Asian immigrants to Britain. Lancet, i, 907.

SERENIUS, F., ElidrisSY, A.T.H. \& DANDONA, P. (1984) Vitamin D nutrition in pregnant women at term and in newly born babies in Saudi Arabia. Journal of Clinical Pathology, 37, 444.

STANBURY, S.W. (1981) Vitamin D and hyperparathyroidism. Journal of the Royal College of Physicians, 15, 205.

(Accepted 23 February 1984) 